\title{
Synthesis and antibacterial activity of some new fused chromenes
}

\author{
Ahmed M. M. El-Saghier, ${ }^{\text {a }}$ Mahbouba B. Naili, ${ }^{\text {b }}$ Bahlul Kh. Rammash, ${ }^{\text {b }}$ Nabil A. Saleh, \\ and Khaled M. Kreddan ${ }^{\mathrm{c}}$ \\ ${ }^{a}$ Chemistry Department, Faculty of Science, Sohag University, Egypt \\ ${ }^{b}$ Chemistry Department, Faculty of Science, Al-Fateh University, P.O. Box 13203 \\ Tripoli, Libya \\ ${ }^{c}$ Libyan Petroleum Institute, P.O. Box 3064 Tripoli, Libya \\ E-mail:el_saghier@hotmail.com,fatma_abeed@yahoo.com,kkreddan@yahoo.com
}

\begin{abstract}
A new class of pyrano[3,4-c]chromene, benzo[c]chromene, chromeno[3,4-c]pyridine and chromeno[4,3-c]pyrazole has been prepared from 3-benzoyl-2 $H$-chromen-2-one 1 . Most of the chromene derivatives showed moderate to high antibacterial activity as compared to the starting material 1.
\end{abstract}

Keywords: $\quad$ Pyrano[3,4-c]chromene, benzo[c]coumarin, chromeno[3,4-c]pyridine, chromeno[4,3-c]pyrazole

\section{Introduction}

During the last twenty years, the study of the biological activities of chromene derivatives has been the aim of many scientists ${ }^{-10}$ Recently, the anticoagulant, antibacterial, anti-helminthic, hypothermal and vasodilatory properties of chromene has been reviewed ${ }^{1}$.. Fused chromenes are interesting due to their significant antibacterial ${ }^{11-15}$ and novobiocin ${ }^{16,17}$ activities. Recently, Selectfluor ${ }^{18}$ was used as an alternative to conventional catalysts for the synthesis of substituted chromenes via Pechmann condensation of phenols with $\beta$-ketoesters under solvent-free conditions. As part of our studies aimed to develop simple and efficient syntheses of polyfunction heterocyclics from readily obtained starting materials ${ }^{19,20}$, we have reported the synthesis of chromenopyridine and thiopyranochromene derivatives by cycloaddition of active methylene compounds with chromene-3-(4-aminosulfonyl) carbanilide $^{19}$ or coumarin-3thiocarboxamide $^{20}$. This prompted us to use 3-benzoyl-2H-chromen-2-one $\mathbf{1}$ as a precursor for the synthesis of polyfused heterocyclic compounds containing pyrano[3,4-c]chromene, benzo $[c]$ chromene, chromeno[3,4-c]pyridine and chromeno[4,3-c]pyrazole derivatives 
employing active methylene compounds possessing $\alpha$-cyano or $\alpha$-keto group using a previously reported protocol. ${ }^{21-24}$

\section{Results and Discussions}

Compound 1 was prepared by cyclocondensation of ethyl benzoylacetate with salicylaldehyde ${ }^{25}$. Compound 1 was then allowed to react with malononitrile in refluxing ethanol containing a catalytic amount of piperidine to give 2-amino-5-oxo-4-phenyl-5,10b-dihydropyrano[3,4-c]chromene-1-carbonitrile 2 . The same product was obtained when malononitrile ${ }^{19}$ was replaced with cyanoacetamide (Scheme 1).<smiles>O=C(c1ccccc1)c1cc2ccccc2oc1=O</smiles>

1<smiles>CCO[P+](C)(C)C(C)C</smiles>

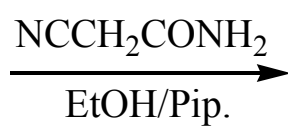

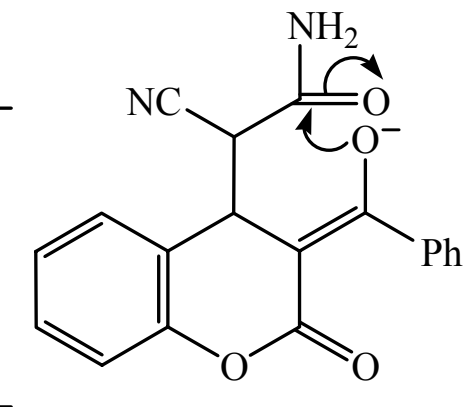<smiles>C=[IH]</smiles><smiles>CC1C(c2ccccc2)=C2C(=O)Oc3ccccc3C2C1(C)C#N</smiles>

\section{Scheme 1}

Treatment of compound 1 with ethyl cyanoacetate under basic conditions, unexpectedly afforded ethyl 10-cyano-9-hydroxy-6-oxo-7-phenyl-6H-benzo[c] chromene-8-carboxylate 3 . The reaction pathway is assumed to proceed by nucleophilic addition of the carbanion to the ethylenic bond of compound 1 affording the expected pyranochromene. Which in turn reacts with a second equivalent of ethyl cyanoacetate ion. Subsequent ring opening followed by recyclization and elimination of $\mathrm{HCN}$ affords the isolated product 3. 


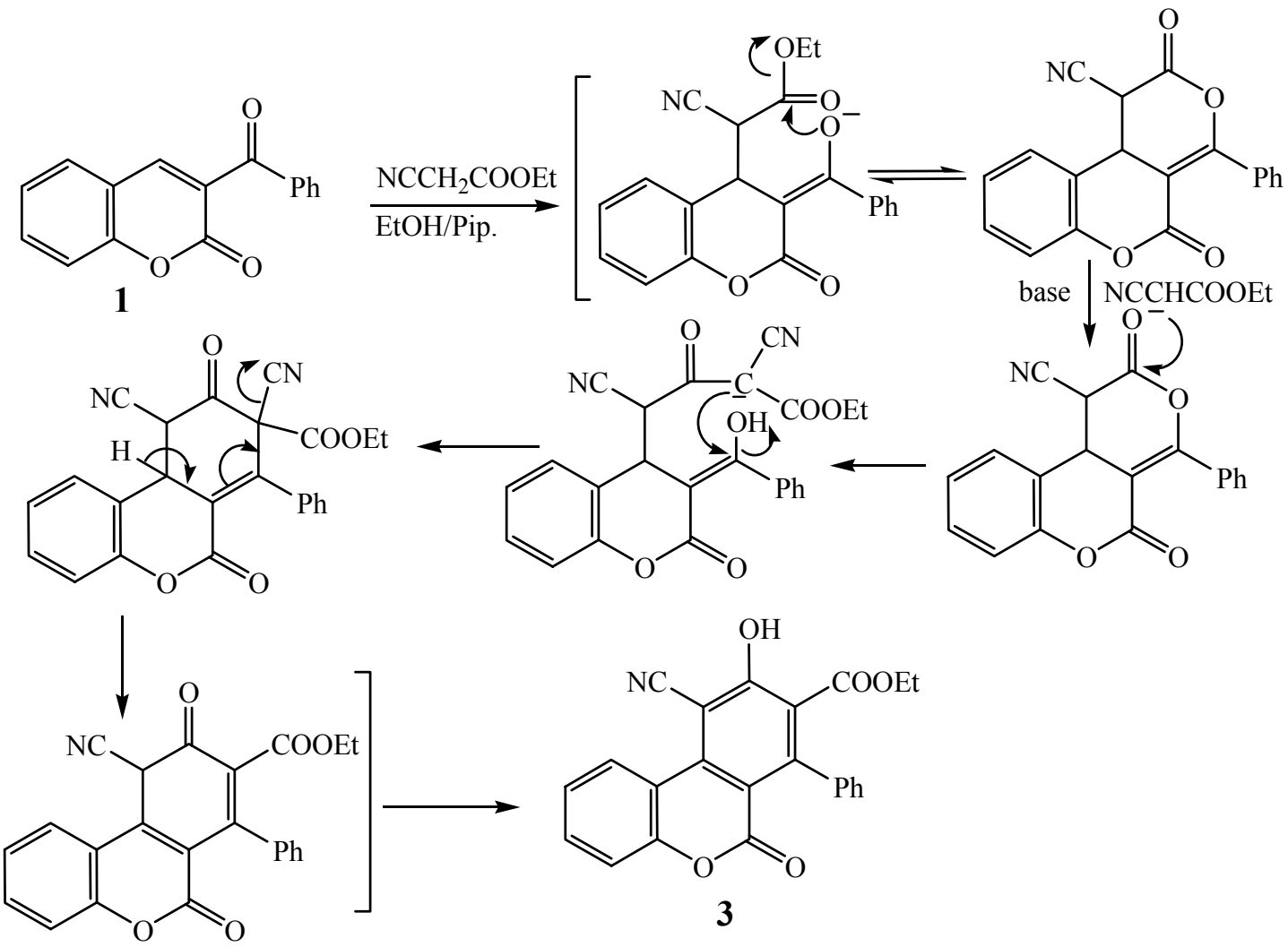

\section{Scheme 2}

The structure of product 3 was supported by IR and ${ }^{1} \mathrm{H}-\mathrm{NMR}$ data. (See Experimental Section).

Similar treatment of compound $\mathbf{1}$ with a series of compounds possessing active methylene groups in refluxing ethanol under basic conditions afforded the pyranochromene and chromenopyridine heterocycles 4-6. 


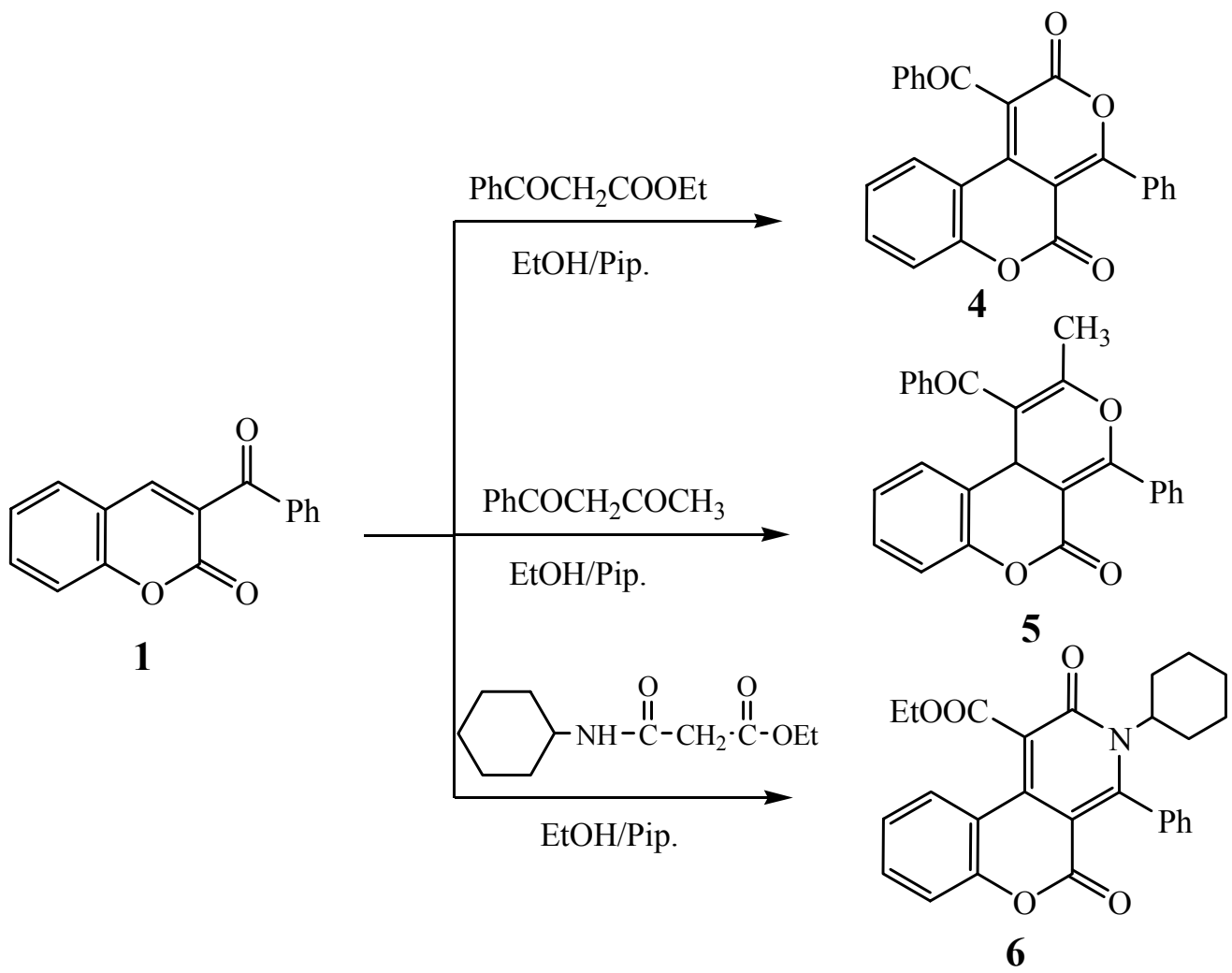

Scheme 3

When compound 1 was reacted with hydrazine hydrate in refluxing ethanol in the presence of triethylamine 3-phenylchromeno[4,3-c]pyrazol-4(1H)-one 7 was formed.<smiles>O=C(c1ccccc1)c1cc2ccccc2oc1=O</smiles>

1<smiles>CCCCC(C)N</smiles>

$\mathrm{EtOH} / \mathrm{TEA}$<smiles>O=c1oc2ccccc2c2[nH]nc(-c3ccccc3)c12</smiles>

7

Attempts to get a 3-cyanocoumarin by treatment of salicyaldehyde with ethyl cyanoacetate ${ }^{17}$ in refluxing ethanol containing a catalytic amount of piperidine, failed. In stead ethyl 2-amino-5oxo-5H-chromeno[3,4-c]pyridine-1-carboxylate 8 was formed. Presumably The reaction proceeds by cyclo condensation of ethyl cyanoactate with salicyaldehyde to give 3cyanocoumarin $^{18}$ which then reacts with a second molecule of ethyl cyanoacetate followed by rearrangement and cyclization. 


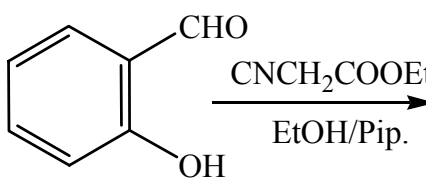<smiles>N#Cc1cc2ccccc2oc1=O</smiles><smiles>CCOC(=O)C(C#N)C1c2ccccc2OC(=O)[C@H]1C#N</smiles><smiles>CCOC(=O)c1c(N)nc(I)c2c(=O)oc3ccccc3c12</smiles><smiles>CCOC(=O)C1C(=N)N=Cc2c1c1ccccc1oc2=O</smiles>

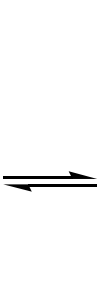<smiles></smiles>

8

\section{Scheme 4}

The structure of compound $\mathbf{3}$ was supported by its IR and 1H-NMR spectra.

Similar treatment of salicylaldehyde with cyanoacetamide in refluxing ethanol containing a catalytic amount of piperidine afforded 2,5-dioxo-3,5-dihydro- $H$-chromeno[3,4-c]pyridine-1carbonitrile 9, most likely 3-cyanocoumarin is formed as an intermediate which reacts with a second equivalent of cyanoacetamide followed by cyclization and eliminating of ammonia and $\mathrm{HCN}$.

The structure of compound 9 was deduced from its IR and 1H-NMR spectra.

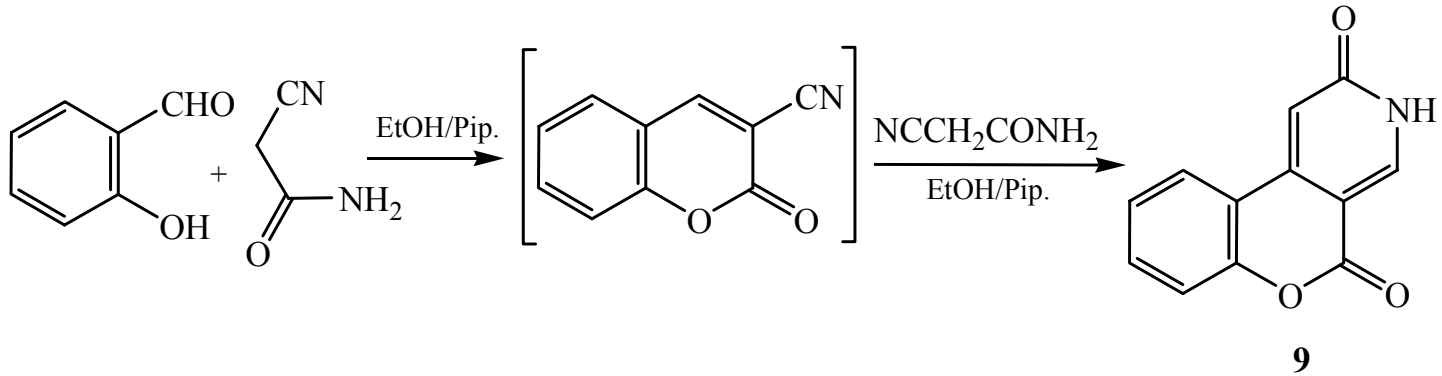

\section{Biological evaluation}

The chromenes (2-9) obtained were preliminarly evaluated for their in vitro antibacterial activity against a narrow spectrum of bacterial species procured from the Laboratory of Microbial Biochemistry (Chem. Dept., Faculty of Science, Al-Fatah Univ.). The paper disc assay described by Cooper ${ }^{26}$ using nutrient agar medium was applied. Suspensions of each microorganism were prepared from their $24 \mathrm{~h}$-cultures to obtain approximately $10^{6}$ colony forming units (cfu) per $\mathrm{ml}$ for plating. Paper discs (Whatman No.1) of $8 \mathrm{~mm}$ diameter were loaded individually with a 
constant amount $(100 \mu \mathrm{g} / \mathrm{disc})$ of the compounds to be tested. Discs were aseptically transferred and applied onto the dry surface of the inoculated plates and then incubated at $37{ }^{0} \mathrm{C}$ for overnight $(\sim 18-20 \mathrm{~h})$. This assay was performed in duplicates and the mean diameters of the clear inhibition zones $(\mathrm{mm})$ were recorded disregard a single colony or a faint haze caused by the inoculums. Results of the in vitro assay of the synthesized compounds are shown in Table 1.

Compounds $\mathbf{2}$ and $\mathbf{3}$ showed mild to moderate activity against the tested Gram-positive and Gram-negative organisms, meanwhile compounds 4, 7, 8, and 9 exhibited comparative and distinctly high activity. Highest antimicrobial activity was observed when the starting compound 1 was annulated with pyrazole or pyridine, except for the $\mathrm{N}$-cyclohexyl derivative $\mathbf{6}$. Although both compound $\mathbf{4}$ and $\mathbf{5}$ are relatively bulky pyrano derivatives, only the former is active. This might be due to the hydrophobic nature of both the methyl and benzoyl groups adjacent to each other in the pyran ring which may cause retardation of the uptake of this compound by microbial cells.

Table 1. In vitro antibacterial activity of the synthesized coumarin derivatives assayed by the paper disc ${ }^{\#}$ method

\begin{tabular}{cccccccccc}
\hline Test compound & 1 & 2 & 3 & 4 & 5 & 6 & 7 & 8 & 9 \\
Test Organisms & & & & & & & & & \\
\hline E. coli NRRL-3704 & 8 & 16 & 15 & 22 & 8 & 8 & 23 & 19 & 22 \\
Salmonella typhi & 8 & 15 & 16 & 21 & 8 & 8 & 22 & 18 & 21 \\
B. subtilis NRRL-4378 & 8 & 17 & 17 & 12 & 8 & 8 & 16 & 22 & 18 \\
Staphylococcus aureus & 8 & 16 & 18 & 20 & 8 & 8 & 18 & 20 & 18 \\
\hline
\end{tabular}

Figures in rows 3-4 represent mean diameters of the clear inhibition zones $(\mathrm{mm})$ induced by the subject coumarin derivatives (2-9) as well as the starting material (1) .

Paper disc diameter $=8.0 \mathrm{~mm} \#$

\section{Experimental Section}

General Procedures. All melting points were determined on a Koffler melting points apparatus and are uncorrected. $\mathrm{H}^{1}$-NMR spectra were recorded on a Bruker Avance $300 \mathrm{MHz}$ spectrometer using TMS as internal reference (chemical shift in $\delta \mathrm{ppm}$ ), and IR spectra in $\mathrm{KBr}$ pellets were obtained on a Bruker FT-IR ISS25 spectrophotometer $\left(\lambda \max\right.$ in $\left.\mathrm{cm}^{-1}\right)$.

2-Amino-5-oxo-4-phenyl-5,10b-dihydropyrano[3,4-c]chromene-1-carbonitrile (2).

Method I. Malononitrile $(0.01 \mathrm{~mol})$ was added to a solution containing compound 1 in $10 \mathrm{ml}$ of ethanol and 3 drops of piperidine. The reaction mixture was refluxed for 3 hours and concentrated to its half-volume. The solid product was filtered off and recrystallized from dioxane,$(70 \%$ yield $)$. 
Method II. Alternatively a solution of compound $1(0.01 \mathrm{~mol})$ and equimolar amount of cyanoacetamide in ethanol $(10 \mathrm{ml})$ containing 3 drops of piperidine was heated to reflux for 4 hours. The solid product was filtered off and recrystallized from dioxane as yellow crystals, yield: 55\%; m. p. $>340{ }^{\circ} \mathrm{C}$; Selected IR frequencies $\left(v \mathrm{~cm}^{-1}\right): 3373,3168\left(\mathrm{NH}_{2}\right), 2957-2814(\mathrm{CH}$ aromatic), $2207(\mathrm{CN})$ and $1661(\mathrm{C}=\mathrm{O}) .{ }^{1} \mathrm{H}$ NMR (300 MHz, DMSO-d 6 : $\left.\delta \mathrm{ppm}\right), 7.00-8.10(\mathrm{~m}$, 9H, arom.), 6.40-6.82 (br, 2H, $\left.\mathrm{NH}_{2}\right), 3.30-3.60\left(\mathrm{br}, 1 \mathrm{H}, \mathrm{CH}\right.$, Pyran). ${ }^{13} \mathrm{C}$ NMR $(70 \mathrm{MHz}$, DMSO-d 6 : $\delta$ ppm), $117.3(\mathrm{C} 1), 77.6(\mathrm{C} 2), 161.3$ (C3), 160.2 (C4), 109.67 (C5), 169.9 (C6), 34.4 (C7) and 121.5-131.1 (benzene ring). Anal. Calc. $\mathrm{C}_{19} \mathrm{H}_{12} \mathrm{~N}_{2} \mathrm{O}_{3}$ : C, 72.15; H, 3.82; N, 8.86 Found: C, 72.35; H, 3.72; N, 8.91.

Ethyl 10-cyano-9-hydroxy-6-oxo-7-phenyl-6H-benzo[c]-chromene-8-carboxylate (3). A solution of (0.01) mole of compound (1) and 0.01 mole of ethyl cyanoacetate and $0.5 \mathrm{ml}$ of piperidine in $10 \mathrm{ml}$ of ethanol was refluxed for 4 hours. The solid product was filtered off and recrystallized from dioxane to yield white crystals, yield: $50 \%$; m. p. $248-250^{\circ} \mathrm{C}$; Selected IR frequencies $\left(\mathrm{v} \mathrm{cm}^{-1}\right)$ : $3407(\mathrm{OH}), 2207(\mathrm{CN}) 1710\left(\mathrm{C}=\mathrm{O}\right.$, ester), and $1684(\mathrm{C}=\mathrm{O}) .{ }^{1} \mathrm{H}$ NMR $(300$ MHz, DMSO-d 6 : $\delta$ ppm), . 9-10 (S, 1H, OH), 7.30-7.80 (m, 9H, arom.), 4.10-4.30 (q, 2H, $\mathrm{CH}_{2}$ ester) and 1.20-1.40 (t, 3H, $\mathrm{CH}_{3}$ ester). ${ }^{13} \mathrm{C}$ NMR (70 MHz, DMSO-d $\left.6: \delta \mathrm{ppm}\right), 115.8(\mathrm{C} 1)$, 100.6 (C2), 165.9 (C3), 114.9. (C4), 155.6 (C5), 124.9 (C6), 169.6 (C7), 148.2(C8) 121.5-129.3 (benzene ring), $169.3\left(\mathrm{C}=\mathrm{O}\right.$ ester), $61.5\left(\mathrm{CH}_{2}\right)$ and $15.0\left(\mathrm{CH}_{3}\right)$. Anal. Calc. $\mathrm{C}_{23} \mathrm{H}_{15} \mathrm{NO}_{5}$ : $\mathrm{C}, 71.68$; $\mathrm{H}, 3.92 ; \mathrm{N}, 3.63$. Found: $\mathrm{C}, 71.33 ; \mathrm{H}, 4.01 ; \mathrm{N}, 3.82$.

Ethyl 3-cyclohexyl-2,5-dioxo-4-phenyl-3,5-dihydro-2H-chromeno[3,4-c]pyridine-1carboxylate (4). A solution of $0.01 \mathrm{~mol}$ of compound (1) was added to a mixture of $0.01 \mathrm{~mol}$ of ethyl benzoylacetate in $15.0 \mathrm{ml}$ of ethanol and $1.0 \mathrm{ml}$ of piperidine. The reaction mixture was refluxed for 5 hours. The solid formed was filtered off and recrystallized from ethanol as pale yellow crystals, yield: $65 \%$; m. p. $135^{\circ} \mathrm{C}$; Selected IR frequencies $\left(v \mathrm{~cm}^{-1}\right): 1730(\mathrm{COPh})$ and 1616, 1607 (C=O groups). ${ }^{1} \mathrm{H}$ NMR (300 MHz, DMSO-d $6: \delta$ ppm), . 7.30-8.20 (m,14H,arom.). ${ }^{13} \mathrm{C}$ NMR (70 MHz, DMSO-d 6 : $\delta$ ppm), $191.9(\mathrm{C} 1), 122.6(\mathrm{C} 2), 165.8(\mathrm{C} 3), 150.6$ (C4), 109.67 (C5), 169.9 (C6), 166.7 (C7) and 121.5-134.6 (benzene ring). Anal. Calc. $\mathrm{C}_{25} \mathrm{H}_{14} \mathrm{O}_{5}$ : C, 76.14; $\mathrm{H}$, 3.58. Found: C, 75.99; H, 3.60.

1-Benzoyl-1-2-methyl-4-phenylpyrano[3,4-c]chromen-5(10bH)-one (5). 3-Benzoyl coumarin $(0.01 \mathrm{~mol})$ was added to a mixture of $0.01 \mathrm{~mol}$ of benzoylacetone in $15 \mathrm{ml}$ of ethanol and $1.0 \mathrm{ml}$ piperidine. The mixture was refluxed for 5 hours. The solid formed was filtered off and recrystallized from ethanol as white crystals, yield: $60 \%$; m. p. $236-238{ }^{\circ} \mathrm{C}$; Selected IR frequencies $\left(\mathrm{v} \mathrm{cm}^{-1}\right): 3065,2982,2920,(\mathrm{CH}$, aliphatic $), 1710(\mathrm{COPh})$ and 1653, $1612(\mathrm{C}=\mathrm{O}$ groups). ${ }^{1} \mathrm{H}$ NMR $\left(300 \mathrm{MHz}, \mathrm{DMSO}_{-} \mathrm{d}_{6}: \delta \mathrm{ppm}\right), .7 .30-8.00(\mathrm{~m}, 14 \mathrm{H}$, arom) and $2.20(\mathrm{~S}, 3 \mathrm{H}$, $\left.\mathrm{CH}_{3}\right) .{ }^{13} \mathrm{C}$ NMR $\left(70 \mathrm{MHz}, \mathrm{DMSO}-\mathrm{d}_{6}: \delta \mathrm{ppm}\right), 171.9(\mathrm{C} 1), 126.6(\mathrm{C} 2), 155.4(\mathrm{C} 3), 1159.7(\mathrm{C} 4)$, 109.67 (C5), 169.9 (C6), 163.6 (C7), 121.5-128.4 (benzene ring), and $15.9\left(\mathrm{CH}_{3}\right)$. Anal. Calc. $\mathrm{C}_{26} \mathrm{H}_{18} \mathrm{O}_{4}$ : C, 79.17; H, 4.60. Found: C, 79.27; H, 4.55. 
Preparation of ethyl 3-(cyclohexylamino)-3-oxopropanoate. Cyclohexylamine (0.01 mol) was mixed with diethyl malonate $(0.01 \mathrm{~mol})$ and heated under reflux for $1 \mathrm{hr}$, after cooling, the product was recrystallized from ethanol as white powder.

\section{Ethyl 3-cyclohexyl-2,5-dioxo-4-phenyl-3,5-dihydro-2H-chromeno[3,4-c]pyridine-1-} carboxylate (6). Compound (1) $(0.01 \mathrm{~mol})$ was added to a solution of ethyl 3-(cyclohexylamino)3 -oxopropanoate $(0.01 \mathrm{~mol})$ in $(15 \mathrm{ml})$ of ethanol and piperidine $(0.015 \mathrm{~mol})$. The reaction mixture was refluxed for $4 \mathrm{hrs}$. The solid product was filtered and recrystallized from dioxane as red crystals, yield: 52\%; m. p. $310-312{ }^{\circ} \mathrm{C}$; Selected IR frequencies $\left(\mathrm{v} \mathrm{cm}^{-1}\right): 3065,2927,2851$ (CH, aliphatic), $1743\left(\mathrm{C}=\mathrm{O}\right.$ ester) and 1726, 1657(C=O group). ${ }^{1} \mathrm{H}$ NMR (300 MHz, DMSO-d $\mathrm{d}_{6}$ : $\delta$ ppm), .20-7.90 (m, 9H , arom.), 4.00-4.20 (q, 2H, $\mathrm{CH}_{2}$-ester) and 1.00-1.85 (m, 3H, $\mathrm{CH}_{3}$ ester + 9H,cyclohexyl.). ${ }^{13} \mathrm{C}$ NMR (70 MHz, DMSO-d 6 : $\delta$ ppm), 171.9 (C1), 122.6 (C2), 160.4 (C3), 148.3 (C4), 109.67 (C5), 169.9 (C6), 163.6 (C7), 121.5-128.4 (benzene ring), 23.3-56.5 (cyclohexyl), 64.1 $\left(\mathrm{CH}_{2}\right)$ and $14.2\left(\mathrm{CH}_{3}\right)$. Anal. Calc. $\mathrm{C}_{27} \mathrm{H}_{25} \mathrm{NO}_{5}$ : C, 73.12; $\mathrm{H}, 5.68 ; \mathrm{N}, 3.16$. Found: C, 72.97; H, 5.47; N, 3.18 .

3-Phenylchromeno[4,3-c]pyrazol-4(1H)-one 7. A mixture of compound (1) $(0.01 \mathrm{~mol}),(0.01$ mol) of hydrazine and $1 \mathrm{ml}$ of triethylamine in $(20 \mathrm{ml})$ of ethanol was refluxed for $1 \mathrm{hr}$. The solid product was filtered and recrystallized from ethanol as orange crystals, yield: $58 \%$; m. p. 230$232{ }^{\circ} \mathrm{C}$; Selected IR frequencies $\left(v \mathrm{~cm}^{-1}\right): 3350(\mathrm{NH})$ and $1625(\mathrm{C}=\mathrm{O}) .{ }^{1} \mathrm{H}$ NMR $(300 \mathrm{MHz}$, DMSO-d 6 : $\delta$ ppm), 8.85 (s, H, NH) and 6.80-7.45 (m, 9H, arom.). ${ }^{13} \mathrm{C}$ NMR (70 MHz, DMSO$\mathrm{d}_{6}$ : $\delta \mathrm{ppm}$ ), 128.1 (C1), $115.2(\mathrm{C} 2), 169.9$ (C3), 118.7 (C4) and 122.5-133.2 (benzene ring). Anal. Calc. $\mathrm{C}_{16} \mathrm{H}_{10} \mathrm{~N}_{2} \mathrm{O}_{2}$ : C, 73.27; H, 3.84; N, 10.68. Found: C, 73.26; H, 3.88; N, 10.59 .

2-Amino-5-oxo-5H-chromeno[3,4-c]pyridine-1-carboxylate (8). A solution of salicylaldehyde $(0.01 \mathrm{~mole})$ and ethyl cyanoacetate $(0.01 \mathrm{~mole})$ in $10 \mathrm{ml}$ of ethanol and $0.5 \mathrm{ml}$ of piperidine was refluxed for 5 hours. The solid formed was filtered and recrystallized from ethanol as white crystals. yield: $70 \%$; m. p. $128-130{ }^{\circ} \mathrm{C}$; Selected IR frequencies $\left(\mathrm{v} \mathrm{cm}^{-1}\right): 3440,3313\left(\mathrm{NH}_{2}\right)$, 2988, 2920 (aliphatic $\mathrm{CH}), 1736\left(\mathrm{C}=\mathrm{O}\right.$, ester) and $1678(\mathrm{C}=\mathrm{O}) .{ }^{1} \mathrm{H}$ NMR (300 MHz, DMSO-d 6 : $\delta$ ppm), 7.05-7.80 (m, 4H , arom.+ 1H pyrido), $4.72\left(\mathrm{~s}, 2 \mathrm{H}, \mathrm{NH}_{2}\right), 4.20\left(\mathrm{q}, 2 \mathrm{H}, \mathrm{CH}_{2}\right)$ and 1.201.40 (t,3H, $\mathrm{CH}_{3}$ ester). ${ }^{13} \mathrm{C}$ NMR (70 MHz, DMSO-d 6 : $\delta$ ppm), $200.1(\mathrm{C} 1), 115.3(\mathrm{C} 2), 165.20$ (C3), 140.34 (C4), 118.7 (C5), 169.9 (C6), 163.6 (C7), 121.5-128.4 (benzene ring) and 18.56 $\left(\mathrm{CH}_{3}\right)$ and $64.67\left(\mathrm{CH}_{2}\right)$. Anal. Calc. $\mathrm{C}_{15} \mathrm{H}_{12} \mathrm{~N}_{2} \mathrm{O}_{3}: \mathrm{C}, 67.16 ; \mathrm{H}, 4.51 ; \mathrm{N}, 10.44$. Found: C, 67.36; $\mathrm{H}, 4.66 ; \mathrm{N}, 10.22$.

2,5-Dioxo-3,5-dihydro-2H-chromeno[3,4-c]pyridine (9). A solution of salicyl- aldehyde (0.01 mole) and cyanoacetamide $(0.01 \mathrm{~mole})$ in ethanol containing piperidine $(0.5 \mathrm{ml})$ was heated under reflux for 4 hours. The solid was filtered off and recrystallized from dioxane as pale yellow crystals, yield: $62 \%$; m. p. $148-150{ }^{\circ} \mathrm{C}$; Selected IR frequencies $\left(\mathrm{v} \mathrm{cm}^{-1}\right): 3356(\mathrm{NH})$, 1689 and $1648(\mathrm{C}=\mathrm{O})$ groups. ${ }^{1} \mathrm{H}$ NMR $\left(300 \mathrm{MHz}, \mathrm{DMSO}-\mathrm{d}_{6}: \delta \mathrm{ppm}\right), 10.80(\mathrm{br}, 1 \mathrm{H}, \mathrm{NH}), 8.20$ (s,1H,pyridine), 7.05-7.80 (m, $4 \mathrm{H}$, arom.+ 1H pyrido). ${ }^{13} \mathrm{C}$ NMR (70 MHz, DMSO-d 6 : $\delta$ ppm), 115.9 (C1), 115.3 (C2), 172.4 (C3), 138.2 (C4), 118.7 (C5), 169.9 (C6), 163.6 (C7) and 121.5128.4 (benzene ring). Anal. Calc. $\mathrm{C}_{13} \mathrm{H}_{6} \mathrm{~N}_{2} \mathrm{O}_{3}$ : C, 65.55; H, 2.54; N, 11.76. Found: C, 65.75; H, $2.53 ; \mathrm{N}, 11.79$ 


\section{References}

1. Soine, T. O. J. Pharm. Sci. 1964, 53, 231.

2. Badran, M. M.; Ismail, M. M.; El-Hakeem, A. Egypt. J. Pharm. Sci. 1992, 33, 1081.

3. El-Farargy, A. F. Egypt. J. Pharm. Sci. 1991, 32, 625.

4. Tunek, H. Monatsh. Chem.; 1962, 93, 684.

5. Nofal, Z. M.; El-Masry, H.; Fahmy. H. H.; Sarhan, I. Egypt J. Pharm. Sci. 1997, 38, 1.

6. Nofal, Z. M., El-Zahar, M. I.; Abd-El-Karim, S. S. Molecules 2000, 5, 99.

7. Priepke, H.; Kauffimann-Hefinar, I.; Damm, K.; Schnapp, A. WO Patent 2003, 2003006443.

8. Vijaykumar, P. R.; Vinod R.; Rajeswar, R. V. Indian J. Chem. 2003, 42, 1738.

9. Venugopala, K. N.; Jayashree, B. S. Indian J. Heterocyclic Chem. 2003, 12, 307.

10. Vaccaro, W.; Yang, B.; Kim, S.; Huynh, T.; Leavitt K.; Li W. WO Patent 2004, 4009017.

11. Okumura, K.; Ashino, K.; Okuda, T. Yakugaku Zasshi 1962, 81, 1482, Chem. Abstr. 1962, $56,7938$.

12. Gingolani, G. M.; Gaultrieri, F.; Pigini J. Med. Chem. 1969, 12, 531.

13. Rao, B.; Mouli, C.; Reddy, Y. D. Ind. J. Chem. 1983, 2B, 176.

14. El-Naggar, A. M.; Ahmed, F. S.; Abd El-Salam, A. M.; Rady, M. A.; Latif, M. S. A. J. Heterocycl. Chem. 1981, 18, 1203.

15. Moustafa M. A. Scientica Pharmaceutica (Sci. Pharm.), 1991, 59, 213.

16. Kaczka, E. A.; Wolf, F. J.; Rathe, F. P; Folkers, K. J. J. Am. Chem. Soc. 1955, 77, 6404.

17. Smissman E. E.; Wilson C. O.; Gisvold, O.; Doerge, R. F. Textbook of organic Medicinal and Pharmaceutical Chemistry, $8^{\text {th }}$ ed., P. 291-292, Lippincott Co.: Philadelphia, Toronto, 1982.

18. Sunil Kumar B., Thirupathi Reddy Y., Narsimha Reddy P., Kumar P. S., Rajitha B. J. Heterocyclic chem., 2006, 43, 477.

19. El-Saghier A. M. M. and Al-Afaleq E. I.; Phosphorus, Sulfur and Silicon, 1998, 139, 67.

20. El-Saghier A. M. M. and Khodairy A.; Phosphorus, Sulfur and Silicon, 2000, 160, 105.

21. El-Saghier A. M. M.; Bull. Chem. Soc., Jpn., 1993, 66, 2011.

22. El-Shafei A. K., Abdel-Ghany H. A., Sultan A. and El-Saghier A. M. M.; Phosphorus, Sulfur and Silicon, 1992, 73, 15.

23. El-Shafei A. K., El-Saghier, A. M. M. and Ahmed E. A. Synthesis, 1994, 152.

24. El-Shafei A. K., El-Sayed A. M. and El-Saghier A. M. M. Phosphorus, Sulfur and Silicon, 1994, 90, 213.

25. Brunskill, J. S. A., Elagbar, A. D. Z., Ewing D. F. and Jeffery; H. Synth. Commun. 1978, 8, 533.

26. Copper K. E., In "analytical Microbiology" Kavangh, F; ed; Academic Press, New York; 1992. 